\title{
Does stress hyperglycemia affect mortality? Acute myocardial infarction - case control study
}

Hayri Cinar ${ }^{1}$, Akkan Avci ${ }^{1}$, Muge Gulen ${ }^{1}$, Begum Seyda Avci ${ }^{2}$, Ertan Comertpay ${ }^{1}$, Salim Satar ${ }^{1}$

${ }^{1}$ Department of Emergency Medicine, Health Science University, Adana City Research and Training Hospital, Adana, Turkey

2Department of Internal Medicine, Health Science University, Adana City Research and Training Hospital, Adana, Turkey

Submitted: 1 July 2019

Accepted: 18 July 2019

Arch Med Sci Atheroscler Dis 2019; 4: e201-e207

DOI: https://doi.org/10.5114/amsad.2019.87303

Copyright $\odot 2019$ Termedia \& Banach

\section{Abstract}

Introduction: We aimed to investigate the effect of stress (acute) hyperglycemia in patients with acute coronary syndrome who had not been previously diagnosed with diabetes mellitus (DM) on the prognosis of the disease in terms of mortality.

Material and methods: Patients who were admitted to the Adana Numune Training and Research Hospital Emergency Service Clinic between August 2010 and August 2013 and whose plasma blood glucose level was over $140 \mathrm{mg} / \mathrm{dl}$ at the time of admission but were not previously diagnosed with DM, who were over the age of 18 and considered to have acute myocardial infarction were included.

Results: A total of 259 patients whose data were fully attainable were included in the study. $80.3 \%(n=208)$ of the patients were male and $19.7 \%$ $(n=41)$ were female. Non-ST elevation myocardial infarction was found in $71.6 \%$, ST elevation myocardial infarction was found in $28.4 \%$ of the patients with stress hyperglycemia. It was determined that $10.1 \%$ of patients with stress-related hyperglycemia and $1.3 \%$ of patients without stress-related hyperglycemia had died.

Conclusions: The plasma blood glucose level at presentation of patients diagnosed with acute myocardial infarction at the emergency room is associated with early in-hospital mortality.

Key words: acute myocardial infarction, hyperglycemia, mortality.

\section{Introduction}

Ischemic necrosis of the myocardium is called myocardial infarction. Despite improvements in medical and interventional treatments in the last 40 years, acute myocardial infarction (AMI) is still an important cause of mortality and morbidity. It has been reported that there are approximately 230,000 new coronary events each year, 160,000 men and 120,000 women die annually and approximately 66,000 men and 61,000 women die annually from a coronary cause, in the long-term study of Cardiac Disease and Risk Factors in Turkish Adults (TEKHARF) in our country [1].

Stress hyperglycemia is a transient increase in blood glucose during acute physiological stress in the absence of diabetes (normal glucose homeostasis before stress). This phenomenon usually will be determined

\author{
Corresponding author: \\ Akkan Avci MD \\ Department of \\ Emergency Medicine \\ Health Science \\ University \\ Adana City Research \\ and Training Hospital \\ 01060 Adana, Turkey \\ E-mail: drakkanavci@gmail. \\ com
}


in critically ill patients and the concentration of glucose varies in the range of $140-300 \mathrm{mg} / \mathrm{dl}$ [2].

Hyperglycemia and impaired glucose tolerance are common during AMI. The hyperglycemia seen at the onset of AMI appears to be related to the introduction of stress mechanisms. This mechanism is a reflection of steroid hormones and insulin resistance, excess of adrenaline, glucagon and high free fatty acids [3]. In fact, this mechanism, which enters the circuit in order to adapt to the stress situation, becomes harmful due to mitochondrial damage, oxidative stress-related damage in cells, endothelial damage and cardiac potassium channel dysfunction, and affects the course of critical illness negatively [4, 5].

We aimed to investigate the effect of stress (acute) hyperglycemia in patients who applied to the Emergency Medical Clinic of our hospital, have been diagnosed with $\mathrm{AMI}$ and had not been previously diagnosed with diabetes mellitus (DM), on the prognosis of the disease in terms of mortality.

\section{Material and methods}

\section{Patient selection}

The study's ethics committee approval was received on September 22, 2013 with decision number 46 of the Ethics Committee of Non-Interventional Clinical Research of Adana Numune Education and Research Hospital's Ethics Committee. Patients admitted to Adana Numune Education and Research Hospital Emergency Service Clinic between August 2010 and August 2013, with a blood sugar level over $140 \mathrm{mg} / \mathrm{dl}$, based on the guidelines of the 2009 American Association of Clinical Endocrinologists (AACE) and the American Diabetes Association (ADA) stress hyperglycemia criteria, but not previously diagnosed with DM, whose medical data were completely accessible, and accepted as AMI according to the European Society of Cardiology (ESC) 2011 Third Universal Myocardial Infarction description. Patients' consent was not taken, because this study was done retrospectively.

\section{Inclusion criteria}

Male and female patients over the age of 18 whose file information was fully accessible and who do not have coronary artery disease (CAD), hypertension (HT), acute/chronic renal disease (ARD/CRD), cerebrovascular event (CVE) and malignancy in their histories; who have not been diagnosed with DM or a glycated hemoglobin $\left(\mathrm{HbA}_{1 \mathrm{c}}\right)$ value measured in the last 3 months was less than 6.5; whose blood sugar at admission was > $140 \mathrm{mg} / \mathrm{dl}$, and the $\mathrm{HbA}_{1 \mathrm{c}}$ level was lower than 6.5 in the last 3 months; who had at least two findings relevant to $\mathrm{AMI}$ in addition to chest pain, electrocardiograpohy (ECG) findings and high CK-MB/high-sensitivity troponin $T$ values at the time of admission to the hospital were included in the study.

\section{Exclusion criteria}

Patients who were younger than 18 were excluded from the study. Patients who had acute coronary syndrome (ACS), HT, ARD/CRD, CVE, or malignancy in their history; who has been diagnosed with $\mathrm{DM}$ or had a $\mathrm{HbA}_{1 \mathrm{c}}$ level measured in the last 3 months over 6.5; who did not have at least 2 symptoms that were relevant to $A M I$ in addition to chest pain, ECG findings and high CK$\mathrm{MB} /$ high-sensitivity troponin $\mathrm{T}$ values at the time of admission; who refused to be admitted to the hospital or refused the angiography and patients who had missing information in their files were excluded.

At the beginning of our study, files of all patients admitted to Adana Numune Training and Research Hospital Emergency Medical Clinic between 2010 and 2013 and hospitalized with acute myocardial infarction were retrospectively reviewed through the hospital automation system. From the file information, the age, sex, preexisting DM and ACS and other comorbid diseases, the blood glucose levels at the time of admission, ECG findings, CK-MB levels at presentation, high-sensitivity troponin $\mathrm{T}$, blood urea nitrogen (BUN), creatinine, sodium (Na), potassium (K), calcium (Ca), white blood cells (WBC), hematocrit $(\mathrm{HCT})$, platelets (PLT), mean platelet volume (MPV), angiography results, hospital admission and outcome data of the patients were obtained.

\section{Statistical analysis}

SPSS 16.0 software was used in the statistical analysis of the data obtained from the study. Categorical measures such as gender were summarized as number and percentage, while other numerical measures were summarized as mean and standard deviation (median and min-max where necessary). The $\chi^{2}$ test was used to compare categorical measurements between groups. Independent groups used the $T$ test if assumptions were made in comparing numerical measures between groups, and the Mann-Whitney $U$ test was used if no assumptions were made. For the general comparison of more than two groups of numerical measurements without normal distribution, the Kruskal-Wallis test was used. Pearson correlation was used when the assumptions of interaction between the numerical measurements were met, and Spearman correlation was used when the assumptions were not met. The statistical significance level was accepted as $p<0.05$ in all tests. 


\section{Results}

A total of 259 patients whose data were fully attainable were included in the study. $80.3 \%(n=$ 208) of the patients were male and $19.7 \%(n=41)$ were female.

The median age of the patients was 60 years (32-104). The median age of the male patients was 58 years (32-104), while the median age of the female patients was 70 years (37-90 years).

When the ECG of patients at the time of admission to the hospital were reviewed, $35.5 \%$ of the patients ( $n=92$ ) were found to have normal sinus rhythm as their first ECG finding. In the ECG of ST-elevation myocardial infarction (STEMI) patients, the most frequent finding was anterior (30.9\%; 80 patients) and lower wall infarction (30.1\%; 78 patients) (Table I).

$64.5 \%$ of the patients $(n=167)$ were diagnosed with non-ST-elevation myocardial infarction NSTEMI and $35.5 \%(n=92)$ were diagnosed with STEMI.

Patients were found to have lesions most frequently (84.9\%) in the left anterior descending artery (LAD) (Table II).

When the coronary angiographic findings of STEMI and NSTEMI patients were compared, there was no statistically significant difference between the groups (Table III).

Stress hyperglycemia was detected in $42.1 \%$ (109 patients) of the patients studied. It was determined that $76.1 \%$ of patients with stress hyperglycemia and $83 \%$ of patients without stress hyperglycemia were male. There was no statistically significant difference between the presence of stress hyperglycemia and patient gender $(p>0.05)$.

It was determined that $54.1 \%$ of patients with stress hyperglycemia and $36.7 \%$ of patients without stress hyperglycemia had a higher WBC value. There was a statistically significant difference between the groups in terms of high WBC values between patients with or without stress hyperglycemia (Table IV).

NSTEMI was found in $71.6 \%$, and STEMI was found in $28.4 \%$ of the patients with stress hyperglycemia; NSTEMI was found in $59.3 \%$ and STEMI in $40.7 \%$ of the patients without stress hyperglycemia. It was observed that the rate of NSTEMI detection in patients with stress hyperglycemia was statistically significantly higher than that of STEMI detection (Table V).

It was determined that $6.4 \%$ of patients with stress hyperglycemia and $1.3 \%$ of patients without stress hyperglycemia had a stenosis at the left main coronary artery (LMCA). Comparing patients with or without stress hyperglycemia, there was a statistically significant difference between the groups in terms of stenosis in the LMCA (Table VI).
Table I. Distribution of ECG findings of patients

\begin{tabular}{|lcc|}
\hline Parameter & Number & Percentage \\
\hline Normal sinus rhythm & 92 & 35.5 \\
\hline Anterior wall MI & 80 & 30.9 \\
\hline Inferior wall MI & 78 & 30.1 \\
\hline Posterior wall MI & 2 & 0.8 \\
\hline Anterior + inferior wall MI & 1 & 0.4 \\
\hline Anterior + lateral wall MI & 1 & 0.4 \\
\hline Inferior + posterior wall MI & 3 & 1.2 \\
\hline Left branch block & 1 & 0.4 \\
\hline Asystole & 1 & 0.4 \\
\hline Total $(n)$ & 259 & 100.0 \\
\hline
\end{tabular}

Table II. Comparison of coronary angiography results of patients

\begin{tabular}{|lcccc|}
\hline Parameter & \multicolumn{2}{c}{ Present } & \multicolumn{2}{c|}{ Absent } \\
\cline { 2 - 5 } & Number & $\begin{array}{c}\text { Per- } \\
\text { centage }\end{array}$ & Number & $\begin{array}{c}\text { Per- } \\
\text { centage }\end{array}$ \\
\hline LCMA lesion & 9 & 3.5 & 250 & 96.5 \\
\hline LAD lesion & 220 & 84.9 & 39 & 15.1 \\
\hline CXA lesion & 140 & 54.1 & 119 & 45.9 \\
\hline RCA lesion & 169 & 65.3 & 90 & 34.7 \\
\hline
\end{tabular}

LCMA - left coronary main artery, LAD - left anterior descending artery, CXA - circumflex artery, RCA - right coronary artery.

Table III. Comparison of coronary angiography findings of STEMI and NSTEMI patients

\begin{tabular}{|lccc|}
\hline Parameter & STEMI (\%) & NSTEMI (\%) & $P$-value \\
\hline LCMA lesion & 5.4 & 2.4 & 0.105 \\
\hline LAD lesion & 82.6 & 86.2 & 0.24 \\
\hline CXA lesion & 53.3 & 54.5 & 0.251 \\
\hline RCA lesion & 58.7 & 68.9 & 0.097 \\
\hline
\end{tabular}

LCMA - left coronary main artery, $L A D$ - left anterior descending artery, CXA - circumflex artery, RCA - right coronary artery.

Table IV. WBC elevation rates in patients with stress hyperglycemia

\begin{tabular}{|lccc|}
\hline Parameter & \multicolumn{2}{c|}{ Stress hyperglycemia } & \multirow{2}{*}{$P$-value } \\
\cline { 2 - 3 } & Yes $(\% / n)$ & No $(\% / n)$ & \\
\hline WBC elevation & $54.1 / 59$ & $36.7 / 55$ & 0.016 \\
\hline
\end{tabular}

The mean duration of hospitalization was 4.05 \pm 2.737 days (range: $1-55$ ).

There was no statistically significant difference between the groups with respect to the length of hospitalization in patients with stress hyperglycemia and those without stress hyperglycemia $(p>0.05)$. 
Table V. NSTEMI/STEMI detection rate in patients with stress hyperglycemia

\begin{tabular}{|c|c|c|c|}
\hline $\begin{array}{l}\text { Stress } \\
\text { hyperglycemia }\end{array}$ & $\begin{array}{l}\text { NSTEMI } \\
(\% / n)\end{array}$ & $\begin{array}{l}\text { STEMI } \\
(\% / n)\end{array}$ & $P$-value \\
\hline Yes & $71.6 / 78$ & $28.4 / 31$ & 0.49 \\
\hline No & $59.3 / 89$ & $40.7 / 61$ & \\
\hline
\end{tabular}

Table VI. Stenosis rates in LCMA between patients with and without stress hyperglycemia

\begin{tabular}{|lccc|}
\hline Parameter & \multicolumn{2}{c}{ Stress hyperglycemia } & P-value \\
\cline { 2 - 3 } & Yes $(\% / n)$ & No $(\% / n)$ & \\
\hline LCMA lesion & $6.4 / 7$ & $1.3 / 2$ & 0.033 \\
\hline
\end{tabular}

Table VII. Comparison of outcome in patients with and without stress hyperglycemia

\begin{tabular}{|lccc|}
\hline Variable & \multicolumn{2}{c|}{ Stress hyperglycemia } & P-value \\
\cline { 2 - 3 } & Yes $(\% / n)$ & No $(\% / n)$ & \\
\hline Exitus & $10.1 / 11$ & $1.3 / 2$ & 0.002 \\
\cline { 1 - 3 } Discharge & $89.9 / 98$ & $98.7 / 148$ & \\
\hline Total & $100 / 109$ & $100 / 150$ & \\
\hline
\end{tabular}

It was determined that $10.1 \%$ of patients with stress-related hyperglycemia and $1.3 \%$ of patients without stress-related hyperglycemia had died. There was a statistically significant difference between the groups in terms of rates of death when patients who had stress-related hyperglycemia and patients who did not were compared $(p<0.05)$ (Table VII).

\section{Discussion}

Cardiovascular diseases are currently the leading cause of death in industrialized countries and are expected to be the same in developing countries by 2020 [6]. Among cardiovascular diseases, death is most commonly caused by coronary artery disease and this is associated with high mortality and morbidity [7]. Coronary artery disease is the leading cause of mortality and morbidity in developed countries [8]. It is the leading cause of death in Turkey $[9,10]$. There are many studies emphasizing that stress hyperglycemia has a negative effect on the mortality and duration of hospital stay of patients with acute cardiovascular disease [11-13].

The mean age in the study performed by Rafael et al. on 834 patients was $64 \pm 13$ (25-94) [14]. In another study, the mean age was $63.3 \pm 13.8$ [15]. The average age in our study was close to the literature. In a study which Aggarwal et al. performed on non-diabetic patients with myocardial infarction, the male to female ratio was $4: 1$ [12]. In a similar study the female to male ratio was found to be $3: 1$ [14]. As is known, female patients are at increased risk for cardiovascular disease after menopause; this has been associated with decreased levels of estrogen. It is thought that the higher rate of women in the data we obtained in our study may be related to the increased risk of female gender. In addition, the average life span of women in our country is higher than that of men [16]. The vast majority of the patients consisted of a group after their $6^{\text {th }}$ decade. As the average life span of women is longer, advancing age is also another reason why more cardiac events occur in women.

It has been reported that WBC elevation in AMI causes a larger thrombus and more inflammation in small lesions and that more heart failure develops in AMI cases with high WBC and this may be a guide for aggressive treatment choice [17, 18]. In a study conducted by Açıkel, they correlated the high WBC level measured at the first admission with severe heart failure and high mortality in the hospital [19]. In our study, WBC was found to be high in AMI patients with stress hyperglycemia. In our study, increased mortality in AMI patients with stress hyperglycemia could be attributed to the increased WBC value.

When the anatomy of the coronary artery is examined, the anterior wall myocardium is fed from the LAD; and the lower wall myocardium is fed from the circumflex artery (CXA) in $85 \%$ of cases and from the right coronary artery (RCA) in 15\% of them. It is known that most of the feeding of the posterior wall myocardium is from the RCA in most cases and less frequently from the CXA [20]. In the abnormal ECG findings of the patients we included in our study, anterior or posterior wall MI was found in 158 patients. The angiographic findings of our patients were found to be predominantly lesions in the LAD and CXA. According to the results of this angiography, it is expected that the patients will show anterior and inferior wall MI intensively on the arriving ECGs.

In patients undergoing coronary angiography for any reason, the incidence of left main coronary artery lesions varies from about $4 \%$ to about $10 \%[21,22]$. Left main coronary artery stenosis was detected in $3.5 \%$ of the patients included in the study. In addition, the angiographic results of the patients with stenosis showed stenosis in the LMCA branches and RCA. In a study performed in arteries in which coronary angiography and stenting were performed, the most common lesion was in the LAD [23]. According to the incidence of coronary artery involvement, it can be said that the arterial distribution in which the lesions are detected is similar to the rates reported in the literature. The most common coronary artery was the LAD in our study. In addition, it was found that when 
the male and female patients were compared, the coronary angiography findings were not statistically significant.

In one study, it was emphasized that hyperglycemia at the time of emergency service admission was a strong predictor of mortality in STEMI patients and that this could be used to determine the risk of the patients [14]. Another study emphasized that stress hyperglycemia following $\mathrm{Ml}$ in non-diabetic patients could be an important predictor of risk stratification and affect treatment strategies [24]. Budzyński et al. found that low-density lipoprotein (LDL) cholesterol, non-high-density lipoprotein (HDL) cholesterol, triglycerides and fasting blood sugars were significantly higher in patients with abnormal HDL cholesterol levels than in patients with normal levels [25]. In a study conducted by Dönmez et al. on 86 patients which examined the mortality of patients who underwent transcatheter aortic valve implantation, they found that fasting blood glucose levels were high in both living and dying patients [26]. In our study, it was observed that the mortality rate in patients with stress hyperglycemia was significantly higher than the group without stress hyperglycemia. In normal aerobic conditions, a significant portion of myocardial energy needs is satisfied by the oxidation of free fatty acids [27]. Oxygen in the veins and attached to myoglobin may be sufficient for only 2 to 6 heart beats. In humans, there is a decrease in the function of the heart's contractile function in the $10^{\text {th }}$ pulse following coronary occlusion [28]. Thus, the myocardium oxygen reserve is consumed within a few seconds from the start of ischemia, and the oxidative phosphorylation, electron transport, and mitochondrial ATP production cease when the tissue oxygen pressure drops below $5 \mathrm{~mm} \mathrm{Hg}$. Reduction of mitochondrial activity results in anaerobic glycolysis becoming the main source of energy, rather than aerobic metabolism [29]. Thirty minutes after AMI, the amount of epinephrine and free fatty acids (FFA) due to the effect of tumor necrosis factor $\alpha$ (TNF- $\alpha$ ) and interleukin-6 (IL-6) in the plasma increase due to stress factors. Increased plasma FFA/albumin ratio and lack of FFA $\beta$-oxidation of myocardial mitochondria in ischemia cause acyl-CoA and acylcarnitine to accumulate in the myocardium. Accumulation of these substances activates $\mathrm{Ca}$ channels while inhibiting the sarcoplasmic Ca pump, Na-Ca and Na-K pumps. This leads to an increase in the amount of cytosolic Ca. This increase in $\mathrm{Ca}$ is directly related to arrhythmia [30-32]. One of the common complications that determine mortality in $\mathrm{AMI}$ is arrhythmias. The most lethal arrhythmia is ventricular fibrillation. Stress hyperglycemia itself may be a factor that causes these arrhythmias.
Apart from necrotic dead tissue in the area of infarction, AMI has a field of apoptotic dead cells in the perimeter of the infarct area [33]. It has been shown that free oxygen radicals (FOR) formed by hyperglycemia triggered apoptosis in cardiomyocytes by triggering the pathway of cytochrome $c$ and KASPAS-3 [34]. While insulin regulates glucose transport via PI-3 kinase, it also stimulates endothelial nitric oxide (NO) synthesis. Increased blood flow through NO-induced vasodilatation accelerates glucose uptake into tissues. An important effect of nitric oxide is the reduction of the expression of adhesion molecules such as vascular cell adhesion molecule-1 (VCAM-1), E-selectin and intercellular adhesion molecule-1 (ICAM-1). NO also inhibits platelet adhesion and platelet interaction with the vascular wall and enhances the inhibitory effect of prostacyclin on platelet aggregation. In the case of insulin resistance, insulin is reduced by vasculoprotective effects via NO. The atherogenic effect through the production of vascular smooth muscle cell proliferation, migration and plasminogen activator inhibitor (PAI-1) production is accelerating [35]. Clinical trials have shown that insulin resistance may also be important in PAl-1 expression and regulation, which is one of the independent risk factors for coronary artery disease [36]. Due to the increase in PAI-1 levels, the susceptibility to impaired fibrinolytic activity and coagulation in hyperinsulinemia is expected [37].

LMCA lesions show a clinically catastrophic course in patients with unprotected coronary artery disease and the frequency of it is low. Cardiogenic shock has been shown to be a serious trend with this lesion, as well as a high mortality rate even after successful revascularization attempts [38-42]. In our study, 7 of the 9 patients with LMCA stenosis were found to have stress hyperglycemia, and this is a statistically significant difference compared to patients without stress hyperglycemia. LMCA lesions lead to global cardiac involvement leading to ischemia and necrosis in a very wide myocardial area, leading to high mortality. Increased glucose levels may also be a factor affecting mortality by adversely affecting the pathophysiological processes.

In conclusion, hyperglycemia is seen in critical disease with the combined effects of increased stress hormones and activated HPA axis, increased cytokine levels and peripheral insulin resistance. This adaptive mechanism is detrimental to uncontrollable hyperglycemia over time due to undesirable effects on the cellular and metabolic levels (mitochondrial damage, oxidative stress-related damage in cells, endothelial damage and cardiac potassium channel dysfunction) and affects the course of the critical illness in a negative way. 


\section{Conflict of interest}

The authors declare no conflict of interest.

\section{References}

1. Onat A, Kahraman G, Ökçün B, et al. Türk Erişkinlerinde Ölüm ve Koroner Olaylar: TEKHARF Çalışması Kohortunun 5-Yıllık Takibi. Türk Kardiyol Dern Arş 1996; 24: 8-15.

2. Moradi S, Keshavarzi A, Tabatabaee SM. Is stress hyperglycemia a predicting factor of developing diabetes in future? Exp Clin Endocrinol Diabetes 2015; 123: 614-6.

3. Oswald GA, Smith CC, Betteridge DJ, Yudkin JS. Determinants and importance of stress hyperglycemia in non diabetic patients with myocardial infarction. $\mathrm{Br}$ Med J 1986; 293: 917-22.

4. Andreelli F, Jacquier D, Troy S. Molecular aspects of insulin therapy in critically ill patients. Curr Opin Clin Nutr Metab Care 2006; 9: 124-30.

5. Robinson LE, Soeren van MH. Insulin resistance and hyperglycemia in critical illness: role of insulin in glycemic control. AACN Clin Issues 2004; 15: 45-62.

6. Murray CJ, Lopez AD. Alternative projections of mortality and disability by cause 1990 2020: global burden of disease study. Lancet 1997; 349: 1498-504.

7. Morrad B. Akut koroner sendromlu ve akut miyokard infarktüslerinde görülen aritmiler. Uzmanlı tezi, Osmangazi Üniversitesi Tıp Fakültesi, Eskişehir, 2015.

8. http://www.who.int/cardiovascular_diseases/en/cvd_ atlas_14_deathHD.pdf

9. Türkiye Kalp Ve Damar Hastalıklarını Önleme Ve Kontrol Programı. Sağlık Bakanlığı; TSHGM, Yayın No:743, 2008 1-115. Erişim:http://www.tkdonline.org/PDFs/Turkiye_ kalp_ve_damar_hastaliklarini_onleme_ve_kontrol_programi.pdf.

10. Sönmez K, Akçay A, Gençbay M, et al. Koroner arter hastalığı anjiyografik olarak saptanmış olgularda risk faktörlerinin dağılımı. Türk Kardiyol Dern Arş 2002; 30: 191-8.

11. Goldberger E, Alesio J, Woll F. The significance of hyperglycaemia in myocardial infarction. New York State J Med 1945; 45: 391-3.

12. Aggarwal HK, Gupta T, Jain D, Acharya HK, Kumar A. Stress hyperglycemia as a prognostic indicator in non-diabetic myocardial infarction patients. Cumhuriyet Tıp Derg 2011; 33: 449-52.

13. Malmberg K, Norhammar A, Wedel H, Rydén L. Glycometabolic state at admission: important risk marker of mortality in conventionally treated patients with diabetes mellitus and acute myocardial infarction: longterm results from the Diabetes and Insulin-Glucose Infusion in Acute Myocardial Infarction (DIGAMI) study. Circulation 1999; 99: 2626-32.

14. Sanjua R, Nunez J, Blasco ML, et al. Prognostic implications of stress hyperglycemia in acute ST elevation myocardial infarction. Prospective Observational Study. Rev Esp Cardiol 2011; 64: 201-7.

15. Pinheiro CP, Oliveira MD, Faro GB, et al. Prognostic value of stress hyperglycemia for in-hospital outcome in acute coronary artery disease. Arq Bras Cardiol 2013; 100: 127-34.

16. http://www.tuik.gov.tr/PreHaberBultenleri.do?id=18619

17. Zanini R, Curellos S, Bonandi L, et al. Etiopathogenesis of acute myocardial infarction: role of early leukocytosis. Cardiologia 1998; 43: 925-31.
18. Kyne L, Hausdorff JM, Knight E, et al. Neutrophillia and congestive heart failure after acute myocardial infarction. Am Heart J 2000; 139: 94-100.

19. Açıkel M. Akut miyokard infarktüsünde akut faz reaktanlarındaki artışın erken dönem prognoz üzerine etkisi. Atatürk Üniversitesi Tıp Dergisi 2001; 33: 17-21.

20. Beydoğan M. İskemik lezyonların lokalizasyonlarının saptanmasında değişiklikleri ile koroner anjiyografi sonuçlarının karşılaştııılması. Uzmanlık tezi. İstanbul Eğitim ve Araştırma Hastanesi, İstanbul 2009.

21. Park SJ, Kim YH. Percutaneous coronary intervention as an alternative to bypass surgery for unprotected LMCA stenosis. Expert Rev Cardiovasc Ther 2008; 6: 1107-14.

22. Eryonucu B, Gümrükçüoğlu HA, Tuncer M. Kliniğimizde kardiyak kateterizasyon uygulanan hastaların iki yıllık sonuçlarııın değerlendirilmesi. Van Tıp Dergisi 2005; 12: 236-42.

23. Dąbek J, Bałys M, Majewski M, Gąsior ZT. Diabetic patients with an acute myocardial infarction in terms of risk factors and comorbidities management: characteristics of the highest-risk individuals. Adv Clin Exp Med 2016; 25: 655-63.

24. Ishihara M, Kojima S, Sakamoto T, et al. Acute hyperglycemia is associated with adverse outcome after acute myocardial infarction in the coronary intervention era. Am Heart J 2005; 150: 814-20.

25. Budzyński J, Tojek K, Wustrau B, et al. The "cholesterol paradox" among inpatients - retrospective analysis of medical documentation. Arch Med Sci Atheroscler Dis 2018; 3: e46-57.

26. Dönmez Y, Urgun OD, Kurt IH. T wave positivity in lead $\mathrm{aVR}$ is associated with mortality after transcatheter aortic valve implantation. Arch Med Sci Atheroscler Dis 2019; 4: e55-62.

27. Barlas S, Tireli E, Dayıoğlu E, Barlas C. Miyokard Metabolizması ve Harabiyeti. Göğüs Kalp ve Damar Cerrahisi Der 1994; 2: 313-7.

28. Brover RW, Meij S, Serruys PW. A model of asynchronous left ventricular relaxation predicting the bi-experimental pressure decay. Cardiavasc Res 1983; 17: 482-8.

29. Bilal MS, Sarıoğlu T. İskemik Miyokard İnjurisi ve İntraoperatif Miyokard Korunmasına Genel Bir Bakış. Türk Göğüs Kalp Damar Cerrahisi Dergisi 1992; 1: 118-26.

30. Russel RA. Changes in myocardial composition after coronary artery occlusion. Am J Physiol 1961; 200: 995-8.

31. Frohlich ED. The heart: as an endocrine organ. Arch Intern Med 1985; 145: 809-11.

32. Oliver MF, Opie LH. Effects of glucose and fatty acids on myocardial ischaemia and arrhythmias. Lancet 1994; 343: 155-8.

33. Monnier L, Mas E, Ginet C, et al. Activation of oxidative stress by acute glucose fluctuations compared with sustained chronic hyperglycemia in patients with type 2 diabetes. JAMA 2006; 295: 1681-7.

34. Cai L, Li W, Wang G, et al. Hyperglycemia-induced apoptosis in mouse myocardium: mitochondrial cytochrome C-mediated caspase-3 activation pathway. Diabetes 2002; 51: 1938-48.

35. Altındal ş. Diyabetik olmayan hipertansif hastalarda insülin direnci. Uzmanlık tezi, Okmeydanı Eğitim ve Araştırma Hastanesi, İstanbul, 2006.

36. Juhan-Vauge I, Alessi MC. Fibrinolysis and risk ofcoronary artery disease. Fibrinolysis 1996; 10: 127-36.

37. Kohler HP. Insulin resistance syndrome: interaction with coagulation and fibrinolysis. Swiss Med Wkly 2002; 132: 241-52. 
38. Marso SP, Steg G, Plokker T, et al. Catheter-based reperfusion of unprotected left main stenosis during an acute myocardial infarction (the ULTIMA experience). Unprotected Left Main Trunk Intervention Multicenter Assessment. Am J Cardiol 1999; 83: 1513-7.

39. Izumikawa T, Sakamoto S, Takeshita S, Takahashi A, Saito S. Outcomes of primary percutaneous coronary intervention for acute myocardial infarction with unprotected left main coronary artery occlusion. Catheter Cardiovasc Interv 2012; 79: 1111-6.

40. Lee SW, Hong MK, Lee CW, et al. Early and late clinical outcomes after primary stenting of the unprotected left main coronary artery stenosis in the setting of acute myocardial infarction. Int J Cardiol 2004; 97: 73-6.

41. Sakai K, Nakagawa Y, Kimura T, et al. Primary angioplasty of unprotected left main coronary artery for acute anterolateral myocardial infarction. J Invasive Cardiol 2004; 16: 621-5.

42. Parma A, Fiorilli R, DE Felice F, et al. Early and mid-term clinical outcome of emergency $\mathrm{PCl}$ in patients with STEMI due to unprotected left main coronary artery disease. J Interv Cardiol 2012; 25: 215-22. 